\title{
Immunophenotype of multinucleated and mononuclear cells in giant cell lesions of bone and soft tissue
}

\author{
I A Doussis, B Puddle, N A Athanasou
}

\begin{abstract}
Aims: To compare the antigenic phenotype of giant cells in giant cell lesions of bone and soft tissue with that of osteoclasts and macrophage polykaryons.

Methods: Formalin fixed, paraffin wax embedded sections of 106 giant cell lesions, 19 granulomatous, and 14 osteoclast containing lesions were immunohistochemically stained for leucocyte common antigen (LCA), CD68, and HLADR.

Results: Osteoclasts and giant cells of giant cell tumour of bone and giant cell reparative granuloma could be distinguished by their generalised absence of HLADR reaction from macrophage polykaryons and giant cells in other giant cell lesions of bone and soft tissue. Staining for LCA, CD68, and HLA-DR was useful in distinguishing reactive histiocytic giant cells and osteoclasts from tumour giant cells.

Conclusions: A panel of macrophage associated antigens should be diagnostically useful in differentiating the histological nature of giant cells in various giant cell lesions of bone and soft tissue.
\end{abstract}

Many bone and soft tissue tumours and tumour-like lesions are characterised by the presence of a variable number of multinucleated giant cells. Diagnosis of these giant cell lesions, in particular those arising in bone, is based on an evaluation of the clinical history of the patient, together with the radiological and histological findings. Giant cell lesions are often difficult to differentiate using conventional histological methods as they can exhibit a variety of morphological appearances and, with the common feature of numerous osteoclastlike giant cells may closely resemble each other. In some cases even distinction between benign multinucleated giant cells and malignant tumour giant cells cannot be made with certainty.

The designation of the diagnosis of giant cell tumour of bone to other giant cell lesions was originally identified as a problem by Jaffe $e t$ al. ${ }^{1}$ Since then, several efforts have been made to understand the pathogenesis as well as the nature and origin of the giant cells present in these lesions. On the basis of histochemical and ultrastructural similarities, the giant cells in giant cell tumour of bone were thought to be derived from fusion of the mononuclear stromal cells, which include proliferating tumour cells. ${ }^{2-4}$ Further studies, including immunohistochemical investigations, however, have shown that the giant cells resemble osteoclasts and are distinct from proliferating stromal cells ${ }^{5}$; on this basis, they have been considered to be part of a cellular reaction in bone to various types of pathological insult. ${ }^{7}$ The origin and nature of the giant cells in other giant cell lesions of bone and soft tissue is also unclear. $^{8}$

We recently characterised the immunophenotypic differences that exist between osteoclasts and macrophage polykaryons. ${ }^{9}$ Human fetal osteoclasts express a highly restricted range of macrophage antigens; foreign body associated macrophage polykaryons have an antigenic phenotype which is similar to that of tissue macrophages. One notable difference between these two giant cells is the expression of HLA-DR on foreign body macrophage polykaryons and its absence on osteoclasts.

\section{Methods}

Paraffin wax blocks of 106 cases of giant cell lesions of bone and soft tissue were retrieved from the files of the Nuffield Orthopaedic Centre and John Radcliffe Hospital (table). Positive controls for osteoclasts comprised 14 cases containing osteoclasts along resorbing bone surfaces; these were derived from specimens of osteoarthritis of the femoral head, fracture callus, and biopsy specimens of hyperparathyroid bone disease. For macrophage

$H L A-D R$ staining of osteoclasts, macrophage polykaryons, and giant cells of giant cell lesions of bone and soft tissue

\begin{tabular}{ll}
\hline Lesion (No studied) & $H L A-D R$ \\
\hline Macrophage polykaryon lesions: & \\
Foreign body reaction (6) & + \\
Tuberculosis (5) & + \\
Sarcoidosis (4) & + \\
Gout (2) & + \\
Giant cell arteritis (2) & + \\
Osteoclast lesions: & - \\
Osteoarthritis (10) & - \\
Fracture callus (2) & \\
Giant cell lesions of bone and soft tissue: & - \\
Hyperparathyroidism (2) & \\
(Brown tumour) & + \\
Osteomyelitis (12) & $-(+\star$ \\
Giant cell tumour of bone (16) & $-\left(+{ }^{\star}\right)$ \\
Giant cell reparative granuloma (10) & + \\
Benign chondroblastoma (6) & + \\
Chondromyxoid fibroma (4) & + \\
Fibrous dysplasia (7) & + \\
Aneurysmal bone cyst (11) & + \\
Non-ossifying fibroma (8) & + \\
Telangiectatic osteosarcoma (4) & + \\
Eosinophilic granuloma (4) & + \\
Benign fibrous histiocytoma (6) & + \\
Giant cell tumour of tendon sheath (16) & +
\end{tabular}

$+>50 \%$ of giant cells positive; - no reaction; $\left(t^{\star}\right)$ Weak staining of $<10 \%$ of giant cells noted in three of 16 cases of giant cell tumour of bone and two of 10 cases of giant cel reparative granuloma of the jaw. 
polykaryons, positive controls were derived from 19 extraskeletal, soft tissue granulomatous lesions containing numerous macrophage polykaryons (tuberculosis, sarcoidosis, gout, giant cell arteritis and foreign body reaction).

All specimens had been fixed in formalin for at least 24 hours; specimens containing bone or calcified material had been fully decalcified in strong acid $\left(5 \% \mathrm{HNO}_{3}, 10 \% \mathrm{HCl} / \mathrm{EDTA}\right.$, or $5 \%$ trichloroacetic acid) for a variable period of time (about six to 48 hours), depending on the amount of calcified material within the lesion and the size of the specimen processed. Blocks had been embedded in paraffin wax and routinely processed for haematoxylin and eosin staining. Sections ( $5 \mu \mathrm{m}$ thick) from these blocks were mounted on silane covered slides. These were stained by an indirect immunoperoxidase technique, as previously described. ${ }^{10}$ Before immunostaining with monoclonal antibodies KP1 and CR3/43, sections were digested with trypsin $\left(0.1 \%\right.$ trypsin; Sigma T-8128) at $37^{\circ} \mathrm{C}$ for 20 minutes. Negative controls consisted of substitution of antibody alone for primary antibody as well as parallel immunostaining with an irrelevant antibody, CAM 5.2, directed against cytokeratin intermediate filaments. ${ }^{11}$

Monoclonal antibodies used in this study were PD7 $/ 26,{ }^{12}$ directed against leucocyte common antigen (LCA), KP1, ${ }^{13}$ directed against CD68, a macrophage-associated antigen, and TAL $1 B 5^{14}$ and CR3 $343,{ }^{15}$ both directed against HLA-DR. These antibodies were used undiluted in this study. They are known to work satisfactorily in tissue sections derived from specimens which have been formalin fixed (with or without decalcification), routinely processed, and paraffin wax embedded. ${ }^{16} 17$

In each giant cell lesion the number of giant cells expressing HLA-DR was determined by counting the reaction of $\mathbf{3 0 0}$ giant cells in three different fields (100 giant cells per field) in serial sections after staining with antibodies Tal $1 B 5$ and CR3/43. Differences in the number of HLA-DR positive giant cells in some giant cell lesions was noted using these two antibodies but this did not vary by more than $5 \%$ between them; as assessed by either antibody, osteoclasts did not express HLADR. Results have been expressed semiquantitatively in the table to take into account this variability and to provide a ready guide which will allow osteoclasts and giant cells, giant cell tumour of bone, giant cell reparative granuloma, and brown tumour to be differentiated from macrophage polykaryons and giant cells in other giant cell lesions. In general, we found that Tal 1B5 reacted with fewer mononuclear cells and giant cells than CR3/43 in sections of decalcified routinely processed bone specimens.

\section{Results}

EXPRESSION OF LEUCOCYTE/MACROPHAGE MARKERS ON OSTEOCLASTS, MACROPHAGE POLYKARYONS, AND GIANT CELLS OF GIANT CELL LESIONS (table)

All osteoclasts, macrophage polykaryons, and giant cells from the bone and soft tissue giant cell lesions studied showed strongly positive membrane staining for LCA, and cytoplasmic staining for CD68 (macrophage associated antigen). All macrophage polykaryons and most mononuclear cells from all the granulomatous conditions examined strongly expressed HLA-DR (fig 1A), as did giant cells in all cases of benign fibrous histiocytoma and giant cell tumour of tendon sheath (table). HLA-DR staining was not seen in osteoclasts found on the resorbing surfaces of cancellous bone trabeculae in osteoarthritic subchondral bone, fracture callus, or in remodelling host bone around the various giant cell lesions within bone. In giant cell tumour of bone, giant cell reparative granuloma, and brown tumours most giant cells $(>90 \%)$ did not react for HLA-DR (figs 2 and 3). Using monoclonal antibody CR3/43, focal weak positive staining for HLA-DR was seen in 3\% and 5\% of giant cells in two cases of giant cell reparative granuloma of the jaw and $2 \%, 5 \%$, and $8 \%$ of giant cells in three cases of giant cell tumour of bone. With monoclonal antibody TAL 1B5, only scattered giant cells $(<1 \%)$ stained for HLADR in these conditions. In the other giant cell lesions of bone more than $50 \%$ of giant cells were HLA-DR positive (fig 1B-D). Almost all giant cells in non-ossifying fibroma and eosinophilic granuloma were HLA-DR positive (fig 1B). Similarly, in areas not associated with remodelling or woven bone trabeculae, giant cells in fibrous dysplasia and telangiectatic osteosarcoma were HLA-DR positive (fig 1C). Reaction of giant cells for HLA-DR was most variable in aneurysmal bone cyst, benign chondroblastoma, and chondromyxoid fibroma. Although in all cases more than $50 \%$ of giant cells were HLA-DR positive (fig 1D), the number of giant cells expressing this antigen varied greatly from case to case. Another feature consistently noted was that HLA-DR staining of giant cells in both benign chondroblastoma and chondromyxoid fibroma was also generally weak.

\section{EXPRESSION OF LEUCOCYTE/MACROPHAGE} MARKERS ON MONONUCLEAR CELLS OF GIANT CELLS

The macrophage content of individual giant cell lesions, assessed by staining for CD68 and HLA-DR, varied widely and was not felt to be of use in the histological differentiation of these lesions. All foam cells (presumed macrophages) were positive for CD68, LCA, and HLA-DR in non-ossifying fibroma, fibrous dysplasia, eosinophilic granuloma, benign fibrous histiocytoma and giant cell tumour of tendon sheath. In one case of pseudosarcomatous or pleomorphic variant of chondromyxoid fibroma of the tibia, both the bizarre mononuclear and multinucleated cells that were present in the fibromyxoid and chondroid stroma strongly reacted for CD 68, LCA, and HLA$D R$, indicating that they were part of the reactive histiocytic component of the lesion.

IDENTIFICATION OF OSTEOCLASTS, REACTIVE HISTIOCYTES, AND GIANT CELLS IN GIANT CELL LESIONS

Both PD7/26 staining for LCA and KP1 stain- 
Figure 1 Indirect

immunoperoxidase staining with monoclonal antibody $C R 3 / 43$ (anti-HLA-DR) showing positive reaction of giant cells (some arrowed) and mononuclear cells in: $(A)$ foreign body granuloma; (B) nonossifying fibroma; (C) fibrous dysplasia (note staining of foamy macrophages and giant cells); (D) aneurysmal bone cyst.

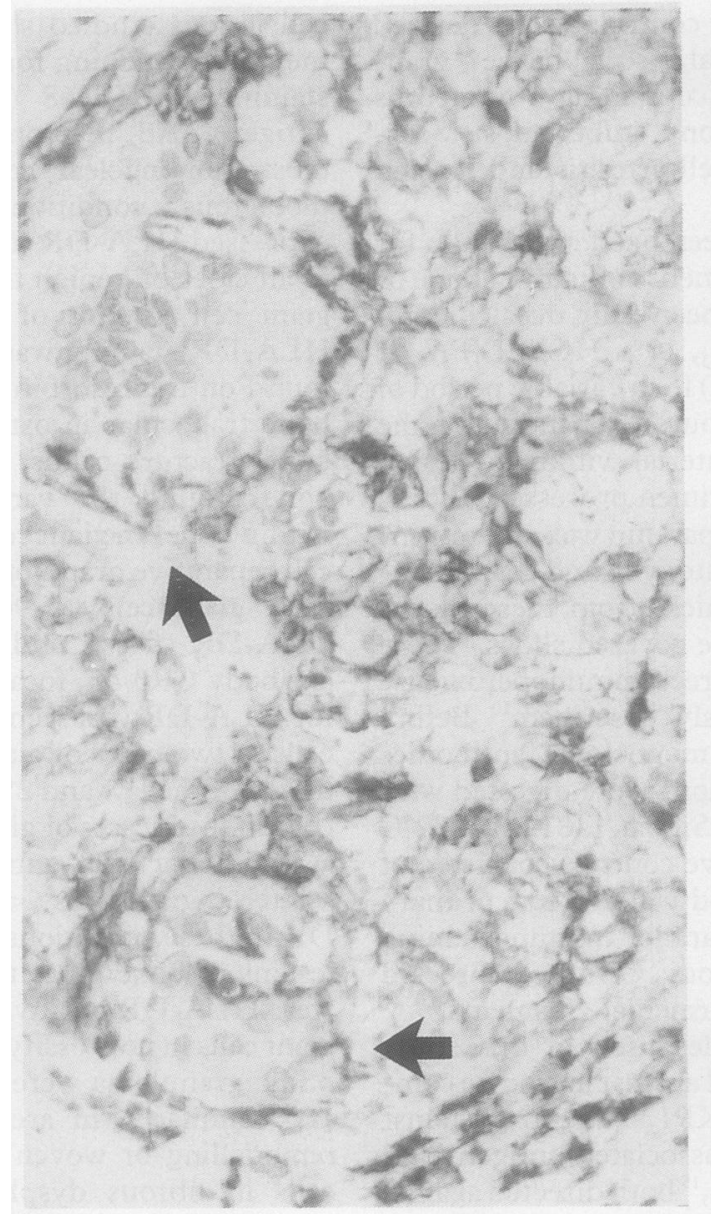

(A)

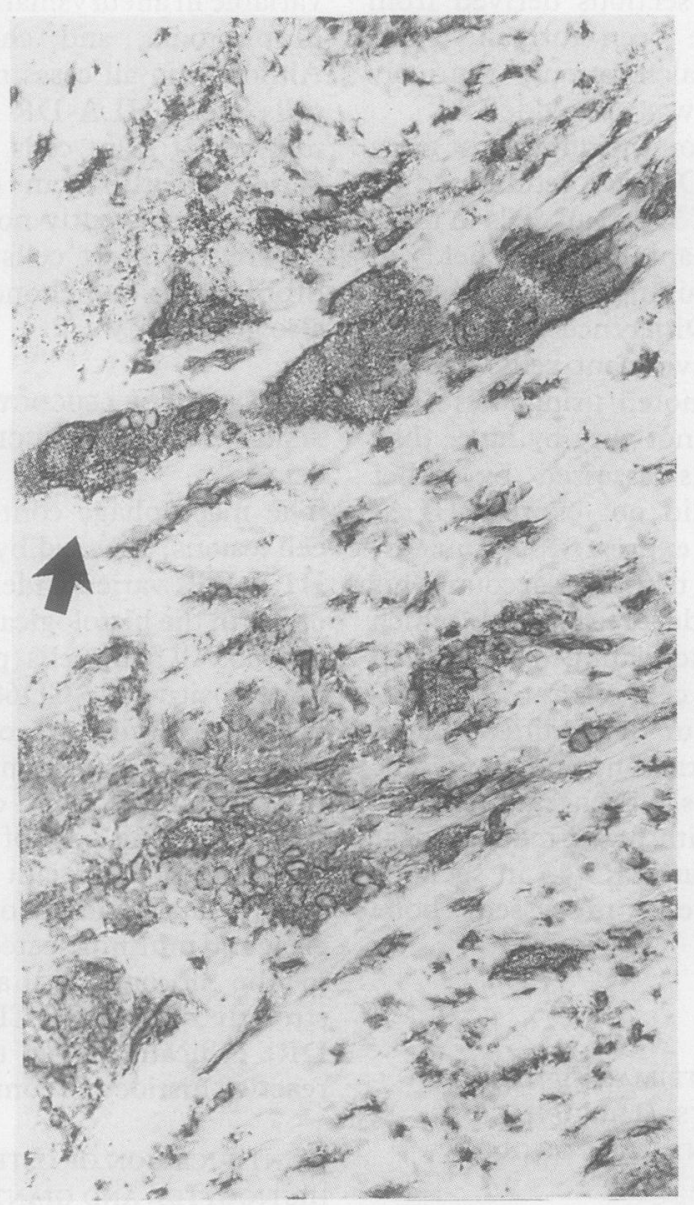

(C)

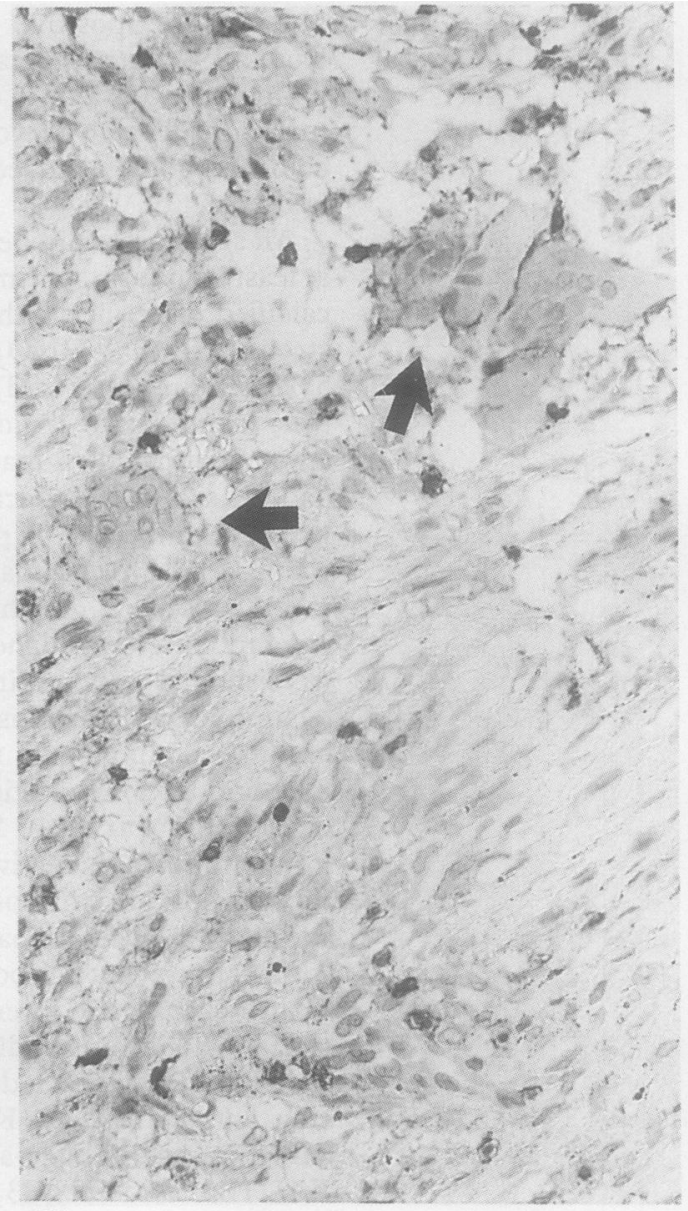

(B)

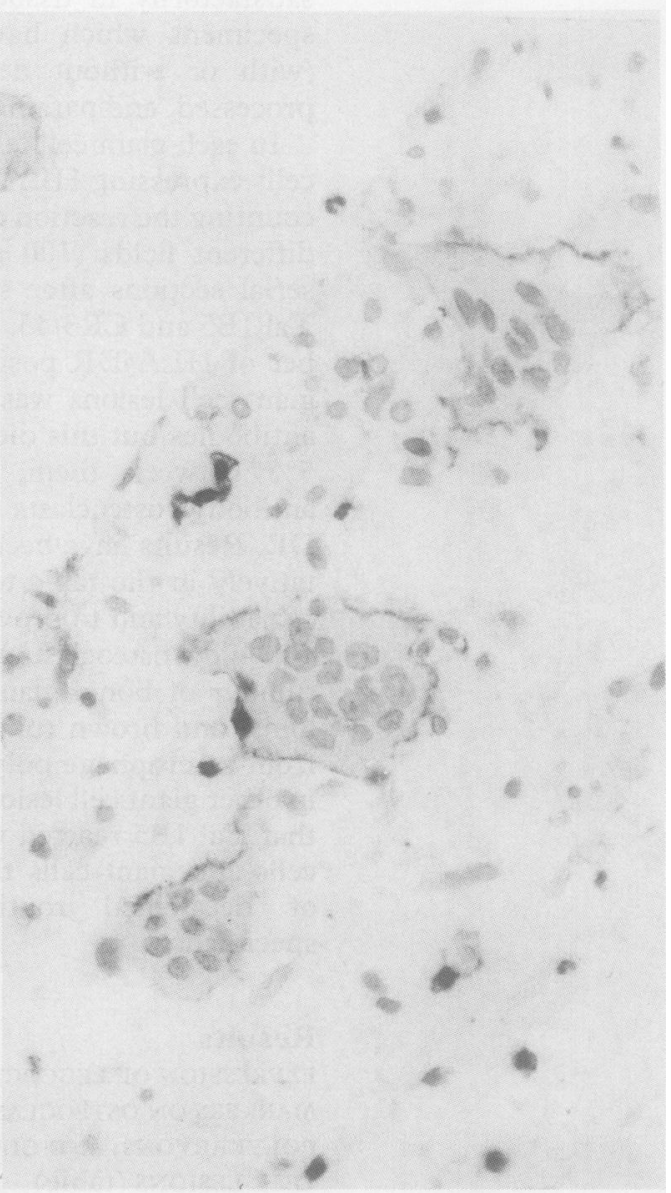

(D) 


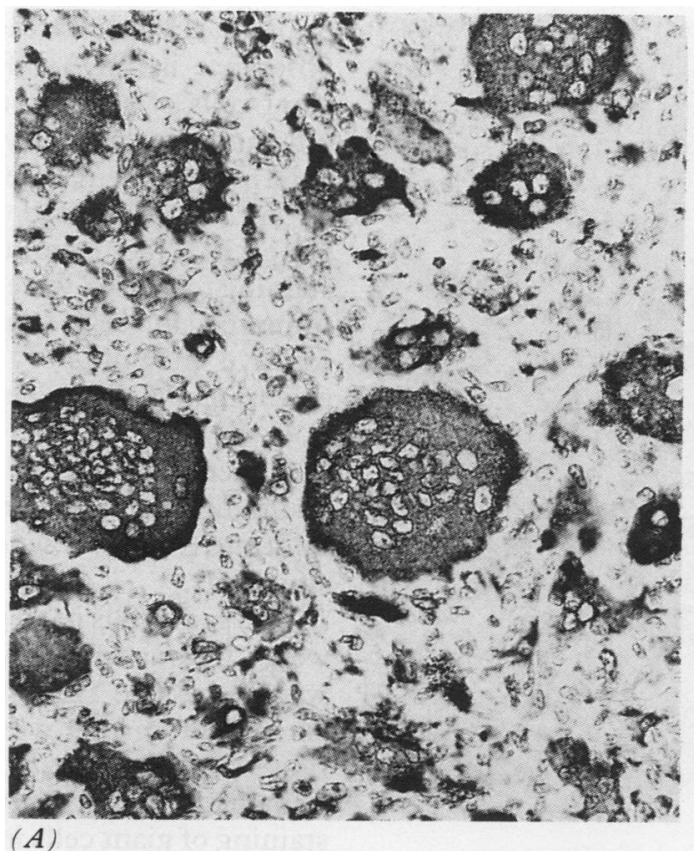

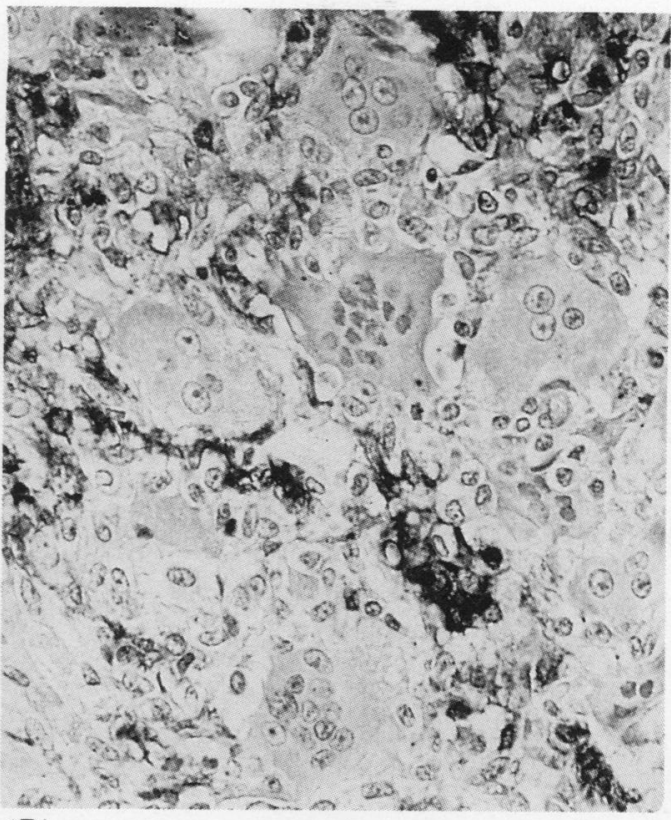

(B)

Figure 2 Indirect immunoperoxidase staining of giant cell tumour of bone with monoclonal antibody: $(A) K P 1$ (anti$C D 68$ ); (B) Tal1 B5 (anti-HLA-DR) showing absence of $H L A-D R$ on $C D 68$ positive giant cells.

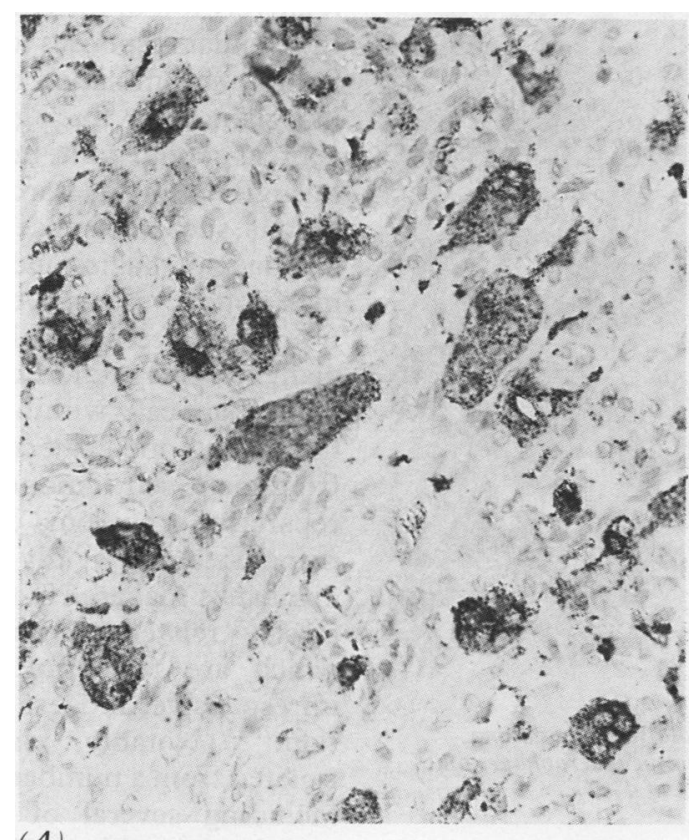

(A)

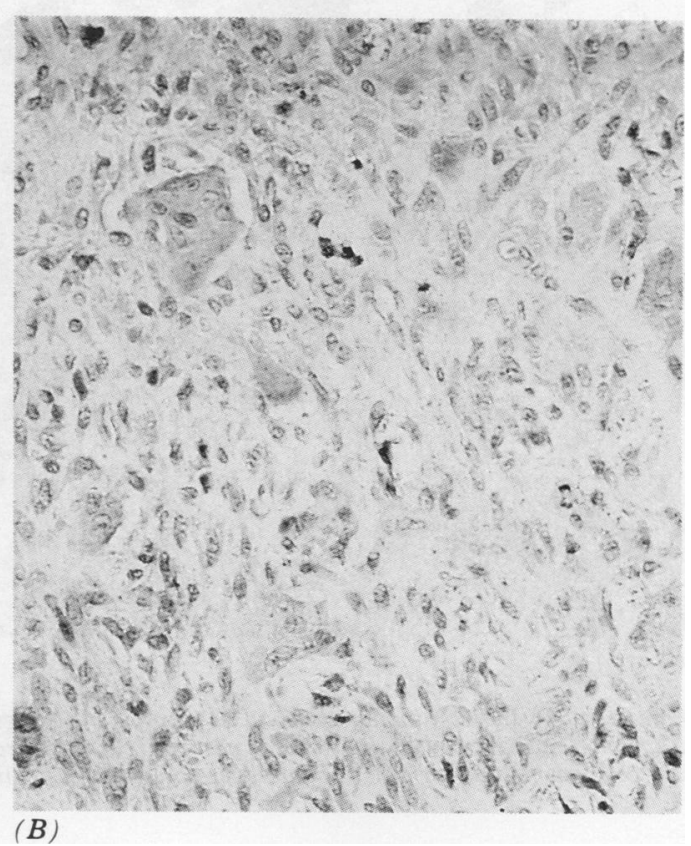

(B) ing for CD68 were useful in distinguishing reactive histiocytes and giant cells from the stromal and tumour cell elements in giant cell lesions. KP1 strongly stains the cytoplasm of osteoclast-like giant cells and, in one case of a telangiectatic osteosarcoma, clearly distinguished reactive histiocytes and osteoclast-like giant cells from tumour cells, including malignant giant cells (fig 4). In another case of a rapidly growing round cell lesion in the clavicle of a boy aged 6, a biopsy specimen was taken and showed some crush artefact; staining with the above two antibodies identified the component cells as histiocytes and also delineated the presence of occasional giant cells, features which were not apparent on the haematoxylin and eosin stained sections. A further use of the differential staining of giant cells for the antigens noted above is illustrated by a case of giant cell tumour of bone which had been needle biopsied before definitive resection, small collections of giant cells being found in the subcutaneous tissue of the biopsy track. Using the different pattern of the HLA-DR reaction of giant cells derived from giant cell tumour of bone and macrophage polykaryons, the type of giant cells could be identified and the possibility of soft tissue implantation of tumour giant cells at the time of biopsy eliminated. 

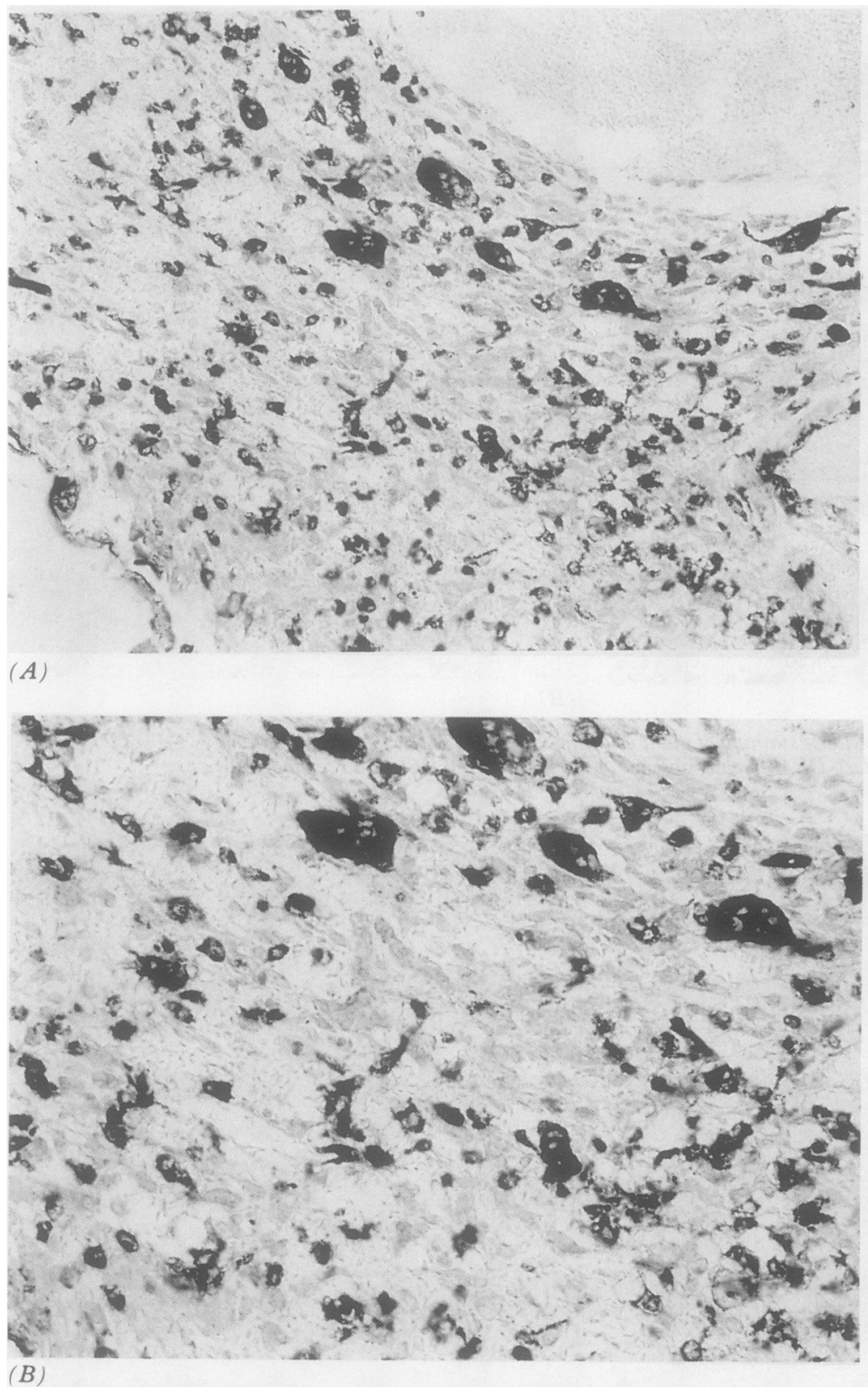

Figure 4 (A) Indirect immunoperoxidase staining of telangiectatic osteosarcoma with monoclonal antibody KP1 showing positive reaction of reactive macrophages and giant cells among tumour cells; (B) Higher power magnification of $4(A)$.

\section{Discussion}

The giant cells in the various giant cell lesions studied were all LCA and CD68 positive, indicating that they are derived from the marrow and can be regarded as members of the mononuclear phagocyte system. Osteoclasts can be distinguished from macrophage polykaryons in routinely processed tissue sections by the absence of immunohistochemical reaction for HLA-DR. ${ }^{17}$ In several giant cell lesions most giant cells showed a similar absence of HLA-DR reactivity. This was most prominent in giant cell tumour of bone, giant cell reparative granuloma of the jaw, and the brown tumour of hyperparathyroidism. We found this difference in giant cell reaction for HLA-DR to be useful in distinguishing these lesions from other reactive and neoplastic giant cell lesions of bone in which most giant cells show a positive HLA-DR reaction. In one case this difference in HLA-DR reaction between the giant cells of a giant cell tumour of bone and inflammatory polykaryons was also useful in determining the nature of the giant cells found in soft tissue around a giant cell tumour of bone. PD7/26 staining for LCA and KP1 staining for CD68 were useful in distinguishing tumour giant cells from osteoclasts and other reactive inflammatory cells in telangiectatic osteosarcoma. They also clearly identified histiocytes and other leucocytes in biopsy specimens and should similarly be of use in distinguishing a benign reactive inflammatory infiltrate from a mesenchymal tumour in other situations.

The giant cells in all giant cell lesions of bone were immunophenotypically heterogeneous with respect to HLA-DR expression. To this extent our results were essentially similar to those of Regezi et al, ${ }^{18}$ who, using a single unnamed antibody, noted strong HLA-DR staining of giant cells in granulomatous inflammatory lesions and slight or no expression in giant cells of giant cell granuloma of the jaw or other bone giant cell lesions, although relatively few of the latter were studied. One of the cellular responses to a pathological insult in bone is accumulation of numerous osteoclastlike giant cells. ${ }^{7}$ Such giant cells are seen in the context of high grade neoplastic lesions, such as telangiectatic osteosarcoma; locally aggressive lesions, such as giant cell tumour of bone; cystic and haemorrhagic conditions, such as aneurysmal bone cyst; as well as in infection and trauma. Differences in HLA-DR expression by giant cells may reflect differences in the nature of the giant cells within such cellular infiltrates. Osteoclasts and giant cells of similar phenotype from giant cell tumour of bone and giant cell reparative granuloma of the jaw are calcitonin responsive and avidly resorptive, ${ }^{1920}$ whereas giant cells that are HLA-DR positive are more closely related to macrophage polykaryons which are primarily phagocytic, calcitonin unresponsive, and less efficient at bone resorption. $^{2122}$ Notably, macrophage polykaryons isolated from a number of extraskeletal tissues, including several of the giant cell lesions examined in this study are capable of bone resorption, ${ }^{22-24}$ but are generally less efficient at effecting such resorption compared with giant cells isolated from giant cell tumour of bone and giant cell reparative granuloma. If the absence of HLA-DR on giant cells accurately reflects whether such cells are primarily resorptive or phagocytic then the proportion of HLADR negative giant cells within different giant cell lesions could explain differences in the resorptive capacity of giant cells isolated from such lesions. It is also possible that this heterogeneity of giant cell HLA-DR expression is reflected in the degree of clinical osteolysis associated with a particular giant cell lesion, lesions showing increased numbers of HLA-DR negative giant cells being larger and more destructive. Alternatively, differences in HLA-DR expression by giant cells may primarily be immunological in origin, reflecting a response to tumour cell proliferation, 
inflammation, or a change in the bone or soft tissue matrix. ${ }^{25}$

The immunophenotypic characteristics of the mononuclear and multinucleated cells are also relevant to a discussion of the cytogenesis and association between various giant cell lesions of bone and soft tissue. Both mononuclear and multinucleated cells in non-ossifying fibroma showed a similar pattern of antigen expression to benign fibrous histiocytoma and giant cell tumour of tendon sheath, soft tissue lesions which it closely resembles morphologically. The pathogenesis of non-ossifying fibroma is uncertain, although on the basis of morphological and ultrastructural observations, it is thought that the basic proliferating cellular element is a fibroblast. ${ }^{26}{ }^{27}$ Foam cells found within the lesion were also thought to be derived from transformed mesenchymal fibroblasts. ${ }^{28}$ Foam cells in non-ossifying fibroma, as well as fibrous dysplasia, eosinophilic granuloma, benign fibrous histiocytoma and giant cell tumour of tendon sheath, however, all stained strongly for LCA, CD68, and HLA-DR, indicating that they are macrophages and not fibroblasts. These are most likely part of the reactive mononuclear histiocytic component of these lesions. Roessner et $\mathrm{al}^{8}$ believe that giant cell tumour of bone should also be regarded as a fibrohistiocytic tumour of bone on the basis that giant cells react with anti-macrophage monoclonal antibodies and numerous infiltrating mononuclear macrophages are present in this lesion. However, giant cells in all giant cell lesions express CD68 (macrophage associated antigen) and CD68 positive mononuclear cells are commonly found in all such lesions. Moreover, not only differences in the reaction for HLA-DR but also differences in the clinical presentation and behaviour of these giant cell lesions in bone are not consistent with this. It is also interesting to note that in the Jaffe-Campanacci syndrome, where multiple non-ossifying fibromas are associated with skin and other extraskeletal anomalies, ${ }^{29}$ giant cell reparative granuloma of the jaw has also been reported. The difference in HLA-DR staining of the giant cells in nonossifying fibroma and giant cell reparative granuloma of the jaw would similarly suggest that they represent distinct entities.

In both benign chondroblastoma and chondromyxoid fibroma CD68, LCA, and HLADR positive giant cells were noted. HLA-DR was weakly expressed by giant cells in these lesions and the number of giant cells expressing HLA-DR, although always greater than $50 \%$, varied greatly from case to case. One case of chondromyxoid fibroma of the tibia also contained numerous bizarre mononuclear and multinucleated cells lying within a fibromyxoid and chondroid stroma. The nature of these cells in this pseudosarcomatous or pleomorphic variant of chondromyxoid fibroma is uncertain. ${ }^{30}$ We have shown that both the bizarre mononuclear and multinucleated cells strongly expressed CD68, LCA, and HLA-DR, indicating that they are a reactive histiocytic component of the lesion rather than degenerate chondroid or myxoid tumour elements. HLA-
DR positive giant cells and macrophages were also commonly found in aneurysmal bone cyst and in the various non-osseous components of fibrous dysplasia. Giant cells found in relation to mineralised tissue in all the lesions studied were HLA-DR negative. This confirms the osteoclastic nature of giant cells lying adjacent to bone.

NAA thanks Professor JM Mirra and Dr CG Woods for many helpful discussions. We also thank Miss Lesley Watts for typing the manuscript. This study was supported, in part, by the the manuscript. This study
Cancer Research Campaign.

1 Jaffe HL, Lichtenstein L, Portis RB. Giant cell tumor of bone. Its pathologic appearance, grading, supposed variants and treatment. Arch Pathol 1940;30:993-1031.

2 Schajowicz F. Giant-cell tumors of bone (osteoclastoma). A pathological and histochemical study. J Bone Joint Surg

Hanaoka H, Friedman B, Mack RP. Ultrastructure and histogenesis of giant-cell tumor of bone. Cancer 1970; 25:1408-23.

4 Steiner GC, Ghosh L, Dorfman HD. Ultrastructure of giant cell tumors of bone. Hum Pathol 1972;3:569-86.

5 Athanasou NA, Bliss E, Gatter KC, Heryet A, Woods CG McGee JO'D. An immunohistological study of giant-cell tumour of bone: evidence for an osteoclast origin of the giant cells. J Pathol 1985;147:153-8.

6 Horton MA, Rimmer EF, Lewis D, et al. Cell surface characterization of the human osteoclast: phenotypic relationship to other bone marrow-derived cell types. J Pathol 1984;144:281-94.

7 Mirra JM. Giant cell tumors. In: Mirra JM, ed. Bone Mirra JM. Giant cell tumors. In: Mirra JM, ed. Bone
tumors: clinical, radiologic and pathologic correlations. tumors: clinical, radiologic and pathologic corr
Philadelphia: Lea and Febiger, 1989:941-1020.

8 Roessner A, Vollmer E, Zwadlo G, et al. The cytogenesis of macrophages and osteoclast-like giant cells in bone tumors with special emphasis on the so-called fibrohistiocytic tumors. Curr Topics Pathol 1989;79:205-27.

9 Athanasou NA, Quinn J. Immunophenotypic differences between osteoclasts and macrophage polykaryons: immunohistological distinction and implications for osteoclast ontogeny and function. J Clin Pathol 1990;43: 997-1003.

10 Gatter KC, Falini B, Mason DY. The use of monoclonal antibodies in histopathological diagnosis. In: Anthony PP, MacSween RNM, eds. Recent advances in histopathology. No 12. Edinburgh: Churchill Livingstone, 1984:35-67.

11 Makin CA, Bobrow LG, Bodmer WF. Monoclonal antibody to cytokeratin for use in routine histopathology. J Clin Pathol 1984;37:975-83.

12 Warnke RA, Gatter KC, Falini B, et al. Diagnosis of human lymphoma with monoclonal antileucocyte antibodies. N Engl J Med 1983;309:1275-81.

13 Pulford KAF, Rigney EM, Micklem KJ, et al. KP1: a new monoclonal antibody that detects a monocyte/macrophage associated antigen in routinely processed tissue sections. $J$ Clin Pathol 1989;42:414-21.

14 Epenetos AA, Bobrow LG, Adams TE, Collins CM, Isaacson PG, Bodmer WF. A monoclonal antibody that detects HLA-D region antigen in routinely fixed, wax embedded sections of normal and neoplastic lymphoid tissues. J Clin
Pathol 1985;38:12-7.

5 Naiem M, Gerdes J, Abdulaziz Z, Nash J, Stein H, Mason DY. Production of monoclonal antibodies for the immunDY. Production of monoclonal antibodies for the immun-
ohistological analysis of human lymphoma. In: Knapp W, et al, eds. Leukaemia markers. New York: Academic Press, 1981:117-25.

16 Athanasou NA, Quinn J, Heryet A, Woods CG, McGee JO'D. Effect of decalcification agents on the immunoreactivity of cellular antigens. J Clin Pathol 1987;40:874-8.

17 Athanasou NA, Puddle B, Quinn JM, Woods CG. Use of monoclonal antibodies to recognise osteoclasts in routinely processed bone biopsy specimens. J Clin Pathol 1991
44:664-6.

18 Regezi JA, Zarbo RJ, Lloyd RV. HLA-DR antigen detection in giant cell lesions. J Oral Pathol 1986;15:434-8.
hambers TJ, Fuller K, McSheehy PMJ, Pringle JAS. The

19 Chambers TJ, Fuller K, McSheehy PMJ, Pringle JAS. The effects of calcium regulating hormones on bone resorption
by isolated human osteoclastoma cells. J Pathol 1985; 145:297-305.

20 Flanagan AM, Chambers TJ. The multinucleate cells in giant cell granulomas of the jaw are osteoclasts. Cancer giant cell granuloma

21 Chamber TJ, Horton MA. Failure of cells of the mononuclear phagocyte series to resorb bone. Calcif Tissue Int 1985;36:556-9.

22 Athanasou NA, Quinn J, Bulstrode CJK. Resorption of bone by inflammatory cells derived from the artificial joint capsule of revision hip arthroplasties. $J$ Bone and Joint Surg 1992;748:59-62.

23 Athanasou NA, Wells CA, Quinn J, Ferguson DP, Heryet A, McGee JO'D. The origin and nature of stromal osteoclast- 
like multinucleated giant cells in breast carcinoma: implications for tumour osteolysis and macrophage biology. Br J Cancer 1989;59:491-8.

24 Athanasou NA, Quinn J, Ferguson DJP, McGee JO'D Bone resorption by macrophage polykaryons of giant cell tumour of tendon sheath. Br J Cancer 1991;63:527-33.

25 Winchester RJ, Kunkel HG. The human Ia system. $A d v$ Immunol 1979;28:221-91.

26 Jaffe HL, Lichtenstein L. Non-osteogenic fibroma of bone. Am J Pathol 1942;18:205-21.

27 Mirra JM. Fibrohistiocytic tumours of intramedullary origin. In: Mirra JM, ed. Bone tumors: clinical, radiologic and pathologic correlations. Philadelphia: Lea and Febiger, 1989:691-800.

28 Bosch AL, Olaya A, Fernandez A. Non-ossifying fibroma of bone. A histochemical and ultrastructural characterizaion. Virchows Arch (Pathol Anat) 1974;362:13-19.

29 Mirra JM, Gold RH, Rand F. Disseminated nonossifying fibromas in association with cafe-au-lait spots (Jaffe-Campanacci syndrome). Clin Orthop 1982;168:192-8.

30 Schajowicz $\mathrm{F}$. Chondromyxoid fibroma (fibromyxoid chondroma). In: Schajowicz F, ed. Tumors and tumor-like lesions of bone and joints. New York: Springer Verlag, 1981:148-60. 